JETE : VOL 2 NO 2 2021* E-ISSN : 2745-9888* P-ISSN : 2745-9896

Journal of Education and Teaching

http://ejournal.uin-suska.ac.id/index.php/JETE

\title{
PEMANFAATAN MEDIA PEMBELAJARAN BERBASIS TEKNOLOGI INFORMASI
}

\author{
Edi Widianto, ${ }^{1}$ Alfina Anisnai'l Husna ${ }^{2}$, Annisa Nur Sasami ${ }^{3}$, Erza Fitri Rizkia ${ }^{4}$, \\ Fitriana Kusuma Dewi ${ }^{5}$, Shindy Aura Intan Cahyani ${ }^{6}$, \\ Universitas Negeri Malang, Indonesia
}

Email: edi.widianto.fip@um.ac.id ${ }^{1}$; alf575369@gmail.com²; anisanursasami@gmail.com³; fitrianad60@gmail.com ${ }^{4}$; erzafitriii@gmail.com4 ${ }^{5}$; sindiaura051@gmail.com $^{6}$

Received: 30 Oktober 2019; Accepted 12 Agustus 2021; Published 1 September 2021

Ed 2021; 2 (2): 213- 224

\begin{abstract}
ABSTRAK
Keberhasilan pendidikan dapat diperoleh dengan proses pendidikan yang berjalan selaras dan terus menerus. Namun, karena kondisi dunia yang sedang dilanda bencana berupa pandemi virus covid-19 maka segala lini kegiatan termasuk pendidikan harus terhambat dan harus dialihkan dengan memanfaatkan media TIK untuk melakukan proses pembelajaran. Media TIK tersebut adalah e-learning. Penggunaan e-learning ini sendiri memiliki berbagai kekurangan serta berbagai hambatan namun juga memiliki kelebihan. untuk menghadapi permasalahan terkait kekurangan dari penggunaan e-learning dalam artikel ini sudah disebutkan berbagai contoh solusi. Berbagai media dapat dimanfaatkan sebagai alat untuk melakukan pembelajaran secara daring atau e-learning contoh diantaranya adalah zoom, google meet dan lain sebagainya. Penggunaan media TIK ini sangat dibutuhkan dan harus dilakukan pada masa masa ini yaitu dengan melakukan proses pembelajaran jarak jauh.
\end{abstract}

Kata Kunci: Media Pembelajaran; Teknologi Informasi; E-learning

\section{PEMANFAATAN MEDIA PEMBELAJARAN BERBASIS TEKNOLOGI INFORMASI}

\begin{abstract}
Educational success can be obtained by an educational process that runs harmoniously and continuously. However, due to the condition of the world being hit by a disaster in the form of a covid-19 virus pandemic, all lines of activities including education must be hampered and must be diverted by utilizing ICT media to carry out the learning process. The ICT media is elearning. The use of e-learning itself has various drawbacks as well as various obstacles but also has advantages. To deal with problems related to the shortcomings of using e-learning in this article, various examples of solutions have been mentioned. Various media can be used as a tool for online learning or e-learning, for example zoom, google meet and so on. The use of ICT media is very much needed and must be done at this time, namely by carrying out a distance learning process.
\end{abstract}

Keywords: Learning Media; Information Technology; E-learning 


\section{PENDAHULUAN}

Pendidikan adalah suatu usaha dalam mencerdaskan kehidupan bangsa. Pendidikan berusaha memupuk kehidupan bangsa yang lebih baik dan sejahtera, serta memperbaiki kualitas sumber daya manusia dalam meningkatkan pembangunan nasional. Suatu tujuan pendidikan dapat diperoleh jika proses pendidikan yang dilaksanakan dapat berjalan secara signifikan, selaras, dan terus menerus.

Adanya wabah covid-19 mengakibatkan kondisi dunia cukup memprihatinkan. Banyak kasus kematian yang terjadi di berbagai belahan dunia akibat adanya wabah pandemi virus corona. Untuk mencegah adanya penularan wabah yang semakin parah maka digalakkan adanya pembatasan-pembatasan pada lingkup warga masyarakat baik sosial maupun fisik dengan menjaga jarak serta penerapan lockdown guna memutus mata rantai penyebaran. Dengan adanya hal ini mengakibatkan banyak aktivitas atau kegiatan masyarakat terhambat khusunya dalam bidang pendidikan. Pendidik dan peserta didik diharuskan untuk melaksanakan proses pembelajaran jarak jauh yang notabenenya membutuhkan media perantara guna menunjang kegiatan belajar dan pembelajaran bisa tetap berjalan secara maksimal.

Keberadaan tegnologi tentunya sudah mendominasi di berbagai kalangan masyarakat, apalagi di era 4.0 atau era industri digital seperti sekarang ini. Sudah banyak aktivitas-aktivitas masyarakat yang memanfaatkan tegnologi sebagai basis termudah dalam kehidupan mereka. Salah satunya adalah pemanfaatan tegnologi dalam bidang informasi dan komunikasi. Jika informasi adalah suatu hal berupa info-info yang didapatkan oleh seseorang yang bermanfaat dalam menambah wawasan dan pengetahuan, maka komunikasi adalah percakapan timbal balik yang dilakukan dua orang atau lebih guna membahas sesuatu hal atau kejadian. Terkadang dalam sebuah kegiatan informasi dan komunikasi tidak serta merta membahas suatu hal yang dianggap penting, adakalanya suatu hal yang dibahas adalah hal menarik, tidak penting, atau hiburan semata. Namun yang pasti, setiap informasi dan komunikasi yang didapatkan bisa terkenang dalam ingatan seseorang jika dikemas dalam sebuah hal yang menarik.

Dalam menyikapi pembelajaran jarak jauh pemanfaatan TIK menjadi hal yang sangat diutamakan dalam menunjang berjalannya proses pendidikan scara maksimal. Adanya TIK berupaya untuk menghilangkan sekat pembatas bagi setiap orang dalam mengakses informasi luas dari berbagai sumber dan tempat, serta bisa melakukan interaksi atau hubungan timbal balik dengan pihak lain yang memiliki jarak cukup jauh dari jangkauan.

Dalam bidang pendidikan penggunaaan TIK mampu mengadaptasi berbagai macam perubahan cara, suasana, serta percepatan yang terjadi dalam lingkup penyelenggaraan pendidikan dengan menerapkan inovasi aktif dan kreatif. Penggunaan TIK tentunya membawa perubahan cukup signifikan dalam prioritas skala aktivitas belajar mengajar baik itu perubahan sistem managemen pengelolaan lembaga, metode mengajar pendidik, serta cara belajar peserta didik. Kebermanfaatan TIK dalam pendidikan mampu memupuk rasa kemandirian serta keaktifan warga belajar, dengan bentuk aktivitas peserta didik menikmati proses belajar berdasarkan usaha mandiri. Usaha mandiri yang dimaksud adalah keaktifan peserta didik dalam mencari dan menganalisis keilmuwannya sendiri berdasarkan spesifikasi dirinya serta kepekaan peserta didik dalam mengolah segala informasi yang ia dapatkan secara kritis. Menjadikan peserta didik yang sebelumnya pasif menjadi peserta didik yang aktif dengan kata lain lebih banyak berusaha menghasilkan dan sharing ilmu pengetahuan 
dan keterampilan dari pada hanya menyerap ilmu yang disampaikan oleh pendidik saja. Sehingga dalam hal ini pendidik hanya berusaha untuk mengarahkan dan tidak serta merta mengaktifkan dirinya untuk mengajar atau mengendalikan peserta didik sepenuhnya. Bisa dikatakan jika seorang pendidik lebih memerankan dirinya sebagai fasilitator sekaligus teman belajar bagi peserta didik. Dengan adanya partisipasi keaktifan yang lebih menekankan pada peserta didik diharapkan kelak mampu menumbuhkan sikap percaya diri, mandiri, optimis, kritis, serta berjiwa lapang dan matang. Selain melakukan pembelajaran secara individu, peserta didik juga dapat melakukan pembelajaran secara berkelompok dengan sharing pemikiran bersama individu lainnya guna memecahkan suatu topik pembelajaran.

Efisiensi dan poin penting TIK dalam dunia pendidikan tentunya sudah tidak diragukan lagi keunggulannya. Dengan TIK menjadikan berjalannya proses pendidikan mudah dan terarah. Mudah lantaran tak harus melakukan tatap muka secara langsung antara pendidik dan peserta didik, mudah lantaran segala bentuk komunikasi dan informasi dapat diakses secara cepat hanya dengan perantara media elektronik yang sudah semakin canggih, serta mudah lantaran TIK memuat berbagai sumber belajar dari berbagai tempat. Selain itu bersifat terarah lantaran TIK mampu disesuaikan dengan berbagai perubahan yang terjadi dalam lingkup pendidikan dan nilai pencapaian keberhasilan senantiasa menyesuaikan dengan tujuan proses. Oleh karena itu, penggunaan TIK cukup efisien dalam menghadapi pembelajaran jarak jauh yang dilaksanakan.

Salah satu metode yang dapat digunakan dalam pemanfaatan TIK sebagai wujud pelaksanaan proses pembelajaran yaitu melaksanakan peran TIK sebagai sumber dan media pembelajaran kreatif dan inovatif bagi peserta didik. Media pembelajaran sendiri merupakan suatu alat atau perangkat baik keras (hardware) maupun lunak (software) sebagai penunjang dalam kemudahan dan keberhasilan proses belajar peserta didik. Pelaksanakan pembelajaran yang menggunakan media lebih memungkinkan dalam kecepatan peserta didik menyerap ilmu dari pembelajaran yang disampaikan. Namun dalam menunjang hal tersebut perlu adanya perhatian seorang pendidik untuk memperhatikan sekitarnya terutama keadaan dan karakteristik peserta didik. dengan adanya media pembelajaran berbasis TIK diharapkan mampu merangsang kepekaan otak, perasaan, perhatian, serta kepeminatan peserta didik dalam belajar sehingga proses pembelajaran yang dilaksanakan bisa berjalan secara baik, efektif, dan maksimal. Selain itu penggunaan TIK sebagai media pembelajaran berupaya dalam mengatasi hambatan dalam proses penerimaan informasi dan komunikasi dari pendidik ke peserta didik baik karena faktor fisiologi, psikologi, sosio kultural, dan lingkungan tempat tinggal. Tentunya media pembelajaran yang baik adalah media pembelajaran yang mampu menarik perhatian peserta didik maka dari itulah dalam hal ini media TIK yang disampaikan jugalah harus memiliki kemenarikan baik dalam hal pengemasan sekaligus isi pembelajaran yang berbobot sehingga hasilnya terasa bermakna oleh peserta didik.

\section{PEMBAHASAN}

\section{Konsep Media Pembelajaran Berbasis Teknologi Informasi dan Komunikasi (TIK)}

Istilah dari teknologi informasi dan komunikasi atau yang lebih dikenal dengan TIK sudah secara luas dikenal sehingga masyarakat mempunyai cara tersendiri untuk memahami makna dari teknologi. Menurut Kukuh Andri Aka (2017) menyatakan 
bahwa kata teknologi informasi dan komunikasi (TIK) secara istilah mencangkup dua makna yang meliputi teknologi informasi dan teknologi komunikasi. Berbagai hal yang berhubungan dengan proses, pemanfaatan alat bantu dan pengelolaan informasi disebut sebagai teknologi informasi. Sedangkan semua hal yang berhubungan dengan pemanfaatan teknologi sebagai alat yang membantu proses dan pemindahan informasi dari suatu perangkat ke perangkat yang lainnya. Sehingga yang membedakan teknologi informasi dengan teknologi komunikasi yaitu teknologi informasi lebih mengacu proses sedangkan teknologi komunikasi lebih mengacu pada produk.

Menurut Rusi Restiyani, dkk (2014) dalam Sudirman 2009 menyatakan bahwa TIK terdiri dari dua komponen yaitu perangkat lunak (software) dan perangkat keras (hardware). Perangkat lunak yaitu semua alat yang dapat disentuh secara fisik. Sedangkan perangkat lunak berupa alat yang berbentuk aplikasi yang dibuat dari pemograman tertentu.

Dalam pemanfaatan teknologi informasi dan komunikasi untuk media pembelajaran mempunyai tujuan dan manfaat. Menurut Shodiq Anshor (2018) menyatakan bahwa pemanfaatan teknologi informasi dan komunikasi dalam pembelajaran mempunyai beberapa fungsi utama yang meliputi: (1) TIK mempunyai fungsi sebagai alat yang berarti teknologi bisa digunakan untuk membantu proses pembelajaran peserta didik maupun pendidik. Misalnya dalam membuat program administratif, membuat grafik dan membuat database; (2) TIK mempunyai fungsi sebagai ilmu pengetahuan, yang berarti TIK dapat digunakan untuk memperoleh segala macam informasi dan menjadi bagian dari disiplin ilmu yang harus dikuasai siswa. Contohnya pada kurikulum 2006 terdapat mata pelajaran TIK; (3) TIK mempunyai fungsi dalam pembelajaran sebagai sumber belajar dan media belajar untuk membantu proses pembelajaran peserta didik dan pendidik.

Sedangkan menurut Hasrah (2019) menyatakan bahwa pemanfaatan teknologi informasi dan komunikasi pada proses pembelajaran mempunyai beberapa manfaat yaitu: (1) menambah mutu kegaiatan pembelajaran; (2) meningkatkan akses pada pembelajaran dan pendidikan; (3) mengembangkan pengambaran dari gagasan-gagasan yang bersifat abstrak; (4) mempermudah memahami materi pembelajaran yang sedang didalami; (5) membuat penampilan dari materi pembelajaran menjadi lebih menarik; dan (6) menjadi penghubung antara materi dengan pembelajaran.

Menurut Syaad Patmanthara (2012) menyatakan bahwa TIK dimanfaatkan pada pendidikan formal, non formal dan informal (PNFI) dalam rangka mendukung pemerataan pendidikan. Sehingga dengan adanya TIK masyarakat di semua jenjang pendidikan dapat mengembangkan ketrampilannya dalam penguasaan teknologi.

Dengan segala fasilitas yang dimiliki oleh teknologi dalam membantu proses pembelajaran, teknologi informasi dan komunikasi menjadi media belajar yang dinilai sangat efektif dan efisien. Menurut Irkham Abdaul Huda (2020) menyatakan bahwa pada perkembangannya, pemakaian teknologi dimanfaatkan untuk sarana belajar secara offline ataupun online. Sehingga pemamfaatan media pembelajaran berbasis TIK memunculkan berbermacam-macam metode belajar, apalagi ketika teknologi tersebut dikembangkan melalui internet.

Pemanfaatan media TIK bersifat offline dapat berupa Computer Basis Learning (CBL). Sedangkan pemanfaatan Media TIK bersifat online dapat berupa Online Learning atau web based learning, dan Distance Learning (Pembelajaran Berbasis Jaringan) atau Integreted System. Menurut Sri Rahayu Chandrawati (2010) telah dijelaskan bahwa e-learning bermakna sebagai suatu proses pembelajaran yang 
memanfaatkan teknologi informasi berupa komputer yang dilengkapi dengan sarana telekomunikasi (internet dan intranet) dan multimedia (grafis, audio, dan video) sebagai media utama dalam penyampaian materi dan interaksi antara pedidik dan peserta didik.

Dengan adanya penerapan e-learning tugas guru dan siswa adalah sama. Menurut Ade Kusmana (2011) menyatakan bahwa terdapat tuntutan bagi guru dan siswa untuk menciptakan suasana belajar yang menyenangkan pada saat pembelajaran jarak jauh. Selain itu untuk mendukung pembelajaran jarak jauh maka dibutuhkan beberapa bantuan. Menurut Hesty Maulida Eka Putry, dkk (2020) menyatakan bahwa proses e-learning bisa terjadi jika memenuhi beberapa hal yang memadai berupa bantuan teknis fisik maupun virtual, koneksi, keputusan desentralisasi, dan transparansi informasi.

Computer Based Learning pada pembelajaran offline sangat penting bagi keberlangsungan pembelajaran online. Jika tidak ada computer based learning maka pembelajaran online tidak dapat dilaksanakan. Hal ini dapat dibuktikan pada gambar berikut ini

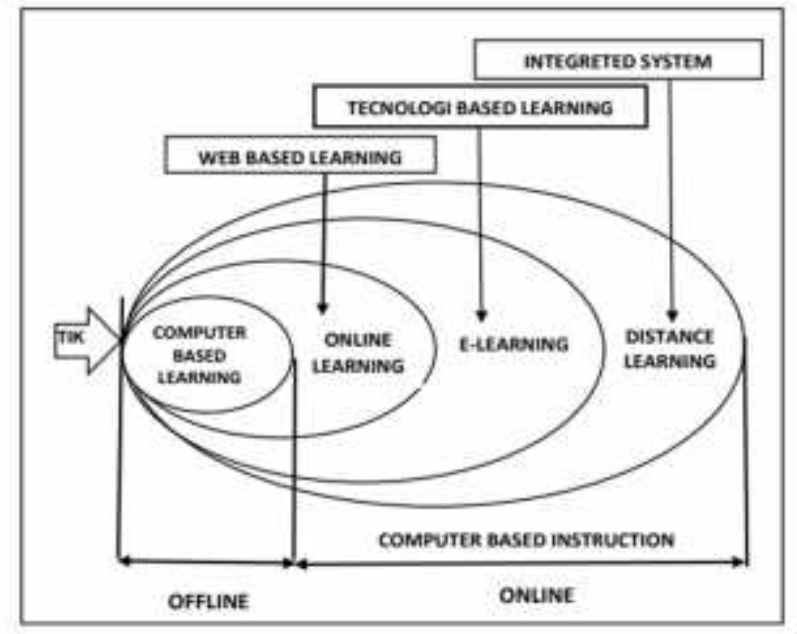

Gambar 1. Hubungan pemanfaatan TIK pada pembelajaran offline dan online

Pada gambar tersebut terlihat bahwa TIK menjadi kunci untuk memfasilitasi terjadinya beberapa proses pembelaran online dan offline. Computer based learning menjadi perantara untuk terjadinya pembelajaran online sehingga disebut sebagai computer based instruction. Menurut Suci Zakiah Dewi, dkk (2018) menyatakan bahwa jenis-jenis media yang digunakan dalam pembelajaran computer based learning antara lain LCD, CD, computer atau laptop, dan printer. Hal ini terjadi karena perangkat multimedia yang dilengkapi dengan groupware pada computer based learning dikoneksikan dengan internet sehingga menghasilkan pembelajaran e-learning. Groupware adalah perangkat lunak yang menjembatani perkumpulan orang-orang secara online sehingga memungkinkan terjadinya pembelajaran jarak jauh.

Dalam pengembangan pemanfaatan TIK sebagai media pembelajaran terdapat beberapa prinsip dasar yaitu: (1) segala proses rancangan pembelajaran memerlukan pendekatan sistem dengan melakukan prosedur yang meliputi identifikasi masalah, analisis masalah, pengelolaan proses belajar, serta penetapan metode dan evaluasi 
belajar; (2) proses pembelajaran yang berlangsung harus menyesuaikan kebutuhan peserta didik; (3) pengembangan sumber belajar agar dapat dengan mudah diakses oleh peserta didik.

TIK sebagai sarana untuk belajar memiliki peranan penting. Menurut Budiana, dkk (2015) menyatakan bahwa TIK dalam pembelajaran dapat di bagi atas dua peran, yaitu: (1) sebagai media presentasi pembelajaran, misalnya berbentuk animasi atau kartun dan power point; (2) sebagai media pembelajaran mandiri atau e-learning, misalnya pendidik memberikan tugas pada peserta didiknya melalui website. Hal tersebut menjadikan peningkatan motivasi belajar siswa. Di mana siswa dirasang untuk melakukan eksplorasi ilmu pengetahuan yang didapatnya. Fasilitas belajar yang bisa dapatkan siswa melalui E-Learning berupa E-Library, E-Book, Email, Mailling List, News Group, dan lain-lain.

Beberapa peran yang dimiliki TIK dalam proses belajar didasari oleh karakteristik dari media yang kompleks. Karakteristik media pembelajaran TIK antara lain: (1) menggunakan perangkat komputer sebagai sarana belajarnya; (2) menggunakan perangkat multimedia sehingga kegiatan pembelajaran menjadi lebih menarik dan tidak membosankan; (3) menggunakan teknologi elektronik sehingga pembelajaran dapat berlangsung secara fleksibel; dan (4) menggunakan sistem pertukaran data yang memungkinkan terjadinya komunikasi yang efektif dari pendidik ke peserta didik dan sebaliknya.

Seiring dengan berkembangan zaman tuntutan penggunaan media pembelajaran berbasis TIK menjadi kebutuhan yang sangat mendesak di dunia pendidikan saat ini. Sehingga dalam pemanfaatannya juga harus didukung dengan pemenuhan kebutuhan terhadap fasilitas TIK. Serta, diperlukannya partisipasi pendidik dalam pengembangannya demi peningkatan mutu belajar peserta didik.

\section{Kelebihan dan Kekurangan Pemanfaatan Media TIK Bagi Peserta Didik dan Pendidik}

Media pembelajaran berbasis teknologi informasi dan komunikasi mempunyai kelebihan dan kekurangan jika dibandingkan dengan penggunaan media pembelajaran lainnya. Kelebihan pemanfaatan media belajar berbasis TIK bagi peserta didik yaitu: (1) memberikan kemampuan siswa untuk belajar secara mandiri. Notabenennya pada saat melakukan pembelajaran tatap muka secara langsung (offline) banyak proses pembelajaran kelas yang menunjukkan bahwasannya pendidik lebih berperan aktif dari pada peserta didik. saat pendidik menyampaikan materi pembelajaran, maka peserta didik hanya berusaha mendengar dan mencatat atau malah kadangkala peserta didik sibuk dengan kegiatan masing-masing seperti bercanda, tidur dan lain sebagainya. Alhasil ilmu yang disampaikan tidak terserap dan membuang banyak waktu serta tenaga. Dengan adanya media TIK memungkinkan segala informasi dan komunikasi bisa didapatkan dan dilaksanakan dengan cepat dan mudah. Sehingga dalam hal ini pendidik tidak perlu repot menjelaskan secara rinci materi pembelajaran yang dibahas, cukup memberikan tanggung jawab kepada peserta didik untuk melakukan akses atau Browsing melalui laman web maka segala sumber pembelajaran bisa didapatkan secara lengkap dan rinci baik berupa modul, buku elektronik, maupun video pembelajaran. Selain itu dengan tersediannya media pembelajaran berbasis TIK menjadikan peserta didik untuk berpartisipasi aktif dalam meningkatkan potensi dan pengetahuannya dengan berbagai sumber informasi yang didapatkan. Jadi tidak selalu fokus dan 
bertumpu pada materi pembelajaran yang ada di kelas saja. peran seorang pendidik dalam hal ini hanyalah berusaha menjadi fasilitator yang baik yaitu berusaha mengarahkan dan mendukung peserta didik dalam berproses sesuai dengan kemampuan intelektual serta ketrampilan dalam mengkritisi suatu topik pembelajaran ; (2) waktu dan tempat belajar bersifat fleksibel. Artinya segala aktivitas belajar dan pembelajaran bisa dilaksanakan kapanpun, dimanapun, dan bagaimanapun dengan perantara memanfaatkan media elektronik; (3) meningkatkan keaktifan dan kreaatifitas siswa dalam mengembangkan pemikirannya. Seperti halnya pada kurikulum K13 yang mengharuskan peserta didik mengembangkan topik pembelajaran yang disampaikan bai berupa praktek atau hasil karya. Maka dalam hal ini keberadaan Media TIK berupaya dalam memupuk jiwa aktif, terampil, kreatif, serta kritis pada individu peserta didik. Peserta didik adalah sosok parsitipan yang mana seorang partisipan selalu berpartisipasi. Bentuk partisipasi bukanlah kepasifan yang hanya diam dan mendengar tanpa bersuara sebagai wujud kemonotonan diri, akan tetapi partisipasi diwujudkan dengan usaha berani berpendapat berdasarkan pemikiran yang bersifat kritis sekaligus berupaya dalam mewujudkan pemikiran yang telah ia susun dalam bentuk karya dan praktek di kehidupan sehari-hari; dan (4) memberikan pengetahuan lebih kepada peserta didik. Namun ada berbagai topik pembahasan ilmu dengan berbagai sumber-sumber baik dalam negeri maupun luar negeri. Sifatnya yang global memudahkan peserta didik dalam menemukan suatu hal yang ingin mereka pelajari sesuai kepeminatan masingmasing. Sementara manfaat bagi pendidik yaitu: (1) pendidik bukan satu-satunya sumber belajar karena meluasnya sumber informasi pada TIK. Sifat TIK yang global menjadikannya basis yang meringankan beban pendidik menghadapi peserta didik. jika seorang pendidik memiliki batasan dalam keilmuwan yang hanya bertumpu pada bidang studi yang dulu pernah ia pelajari dan dikatamkan dengan gelar strata, maka TIK bisa lebih meluas pada segala bidang keilmuwan yang bersifat global; (2) membantu menguatkan kegiatan belajar sehingga dapat merangsang dan memotivasi peserta didik. Peran pendidik sejak adanya media TIK berubah peran menjadi fasilitator yang bertugas memfasilitasi sekaligus memberikan pengarahan kepada peserta didik atas topik pembahasan materi yang sedang terjadi; (3) membantu proses interaksi guru atau tutor dengan peserta didik. Dengan kedatangan Media pembelajaran TIK menjadikan proses pembelajaran yang terlaksana bisa berjalan dengan lancar dan mencapai tujuan yang maksimal. Hal ini terutama berdampak pada pendidik dan peserta didik yang tetap dapat melakukan interaksi baik asingkronus maupun singkronus dengan melalui perantara media; dan (4) pengaturan proses belajar lebih efektif. Dalam hal ini keberadaan media TIK berusaha dalam memenuhi kebutuhan belajar peserta didik dan memudahkan pendidik dalam mentransferkan pengetahuan baik langsung ataupun tidak langsung. Menurut Martius Tekege (2017) menyatakan bahwa keefisiensian Media TIK yang dapat diakses kapanpun dimanapun dan bagaimanapun menjadi landasan efektifitas proses belajar peserta didik. Karena bagaimanapun ada waktu di jam tertentu dimana peserta didik mengalami masa produktif dalam belajar dan ada masa dimana peserta didik mengalami kejenuhan dalam melakukan kegiatan pembelajaran.

Kekurangan media pembelajaran berbasis TIK bagi peserta didik yaitu: (1) Sering terjadi penyalahgunaan teknologi oleh peserta didik. Terkadang bagi peserta didik sesuatu yang menarik bagi dirinya adalah prioritas utama, seperti halnya pemanfaatan tegnologi bagi peserta didik. Salah satunya adalah game online yang dianggap menarik dan menghibur bagi banyak peserta didik. Jika sudah bermain game 
maka mereka akan lupa waktu dan mengabaikan kewajiban dan peranan mereka sebagai sosok peserta didik yang harusnya menimba ilmu dan mengembangkan keilmuwan yang didapatkan; (2) penggunaan web sering susah diakses. Terkadang wilayah yang terkendala jaringan atau sinyal membuat kesulitan saat melakuka browsing atau menelusuri situs, akibatnya menjadikan proses pembelajaran yang dilaksanakan terhambat, selain itu kendala yang terjadi mengakibatkan ketidaknyamanan peserta didik terutama rasa jenuh saat menunggu jaringan pulih; (3) penyampaian informasi yang dilakukan pendidik secara lisan tidak terlalu jelas. Kendala jaringan yang sering terjadi selalu menghambat proses berjalannya pendidikan terutama berkomunikasi. Apalagi komunikasi yang disampaikan membahas poin-poin penting dala hal seputar materi pembahasan. Selain itu, kekurangan media pembelajaran berbasis TIK bagi pendidik yaitu: (1) sering ditemukan pendidik yang tidak bisa mengoprasikan teknologi menjadikan proses pembelajaran tidak dapat berjalan dengan lancar, Tak semua pendidik selalu melek akan teknologi terutama pendidik yang sudah senior. Mereka lebih mengutamakan cara manual atau offline daripada melalui media perantara secara online. Tuntutan untuk bisa mengoperasikan tegnologi terutama teknologi pembelajaran TIK tentu sangat memberatkan bagi mereka; (2) Pendidik tidak bisa menjamin keberhasilan pembelajaran karena kesuksesan tergantung pada kemandirian belajar siswa. Kemandirian peserta didik dalam mencari dan mengembangkan keilmuwannya secara individu tidak serta merta dibarengi keselarasan, kesetaraan, dan kesamaan, tiap peserta didik dalam menyerap ilmu pengetahuan yang ada. Mereka memiliki cara belajar yang berbeda, dan hasil yang berbeda sehingga dalam hal ini pendidik harius memiliki kepandaian dalam menentukan evaluasi seperti apa yang baik dan efektif ia laksanakan untuk mengetahui tolak ukur pengetahuan seluruh peserta didik; dan (3) pendidik sulit untuk mengatur batasan akses pembelajaran sehingga sering disalahgunakan oleh pendidik. Adanya kemudahan dalam aktivitas mengakses terkadang tidak dibarengi dengan kebijakan lingkup akses yang harus dilakukan dan tidak dilakukan. Sehingga dalam hal ini terjadi penyalahgunaan atau penyimpangan dari hal yang sebelumnya tidak harus dilakukan.

\section{Permasalahan dalam Pemanfaatan TIK}

Pada dunia kehidupaan sekarang, adanya teknologi informasi memegang peran yang penting terutama dalam dunia pendidikan. Seperti adanya penerapan teknologi informasi dalam pendidikan yaitu pemanfaatan media internet dalam kegiatan belajar dan mengajar. Dengan adanya pembelajaran menggunakan media internet tersebut diharapkan dapat mempermudah para peserta didik dalam mendapat infomasi yang mereka butuhkan, sehingga peserta didik akan lebih aktif lagi dalam menggali informasi dan pengetahuan yang sedang mereka butuhkan.

Di negara Indonesia, penerapan teknologi informasi komunikasi masih ternilai sangat kurang. Hal ini dibuktikan dengan penerapan TIK dalam pendidikan yang masih berada pada tahap permulaan dan belum dapat digunakan manfaatnya secara maksimal. Beberapa kendala atau masalah yang menyebabkan permasalahan dalam penarapan TIK tersebut antara lain

Infrastruktur yang mendukung penerapan dari teknologi informasi dan komunikasi belum meluas atau merata. Padahal infrastruktur adalah hal yang dinilai begitu penting, karena tanpa infrastruktur yang mendukung dalam implementasi TIK hanya akan menjadi angan-angan saja. Fungsi infrastruktur sendiri adalah untuk modal asal dan modal yang utama untuk penerapan dari TIK. Selain itu masih banyak juga 
daerah-daerah di Indonesia yang belum mendapatkan akses teknologi informasi, contohnya belum mendapatkan akses untuk telepon apalagi akses untuk internet. Padahal sebenarnya daerah tersebut memiliki banyak sekali kapasitas sumber daya manusia yang bernilai unggul. Apabila hal tersebut terus terjadi, dikhawatirkan sumber daya manusia dalam kawasan tersebut akan tersisih dan tidak dapat dipergunakan untuk kemajuan negara Indonesia. Contoh berikutnya adalah lembaga pendidikan yang bertempat di kawasan pelosok belum memiliki sarana maupun prasarana yang mendukung dan memadai, walaupun sekolah-sekolah tersebut memiliki tapi masih sangat minim jumlahnya dan mutu peralatan tersebut kurang baik karena masih menggunakan perangkat media bekas yang ada di lembaga pendidikan tersebut. Perangkat media tersebut masih mengunakan spesifikasi yang lama sehingga akibat penggunaan perangkat tersebut menyebabkan tidak mampu berlomba dengan perkembangan teknologi informasi dan komunikasi yang berjalan semakin cepat.

Kendala selanjutnya yaitu ketidaksiapan sumber daya manusia dalam memanfaatkan teknologi informasi komunikasi dalam kegiatan pembelajaran. Menurut Azhar Arsyad (1997) menyatakan bahwa secara lebih khusus, pengertian media dalam proses belajar mengajar cenderung diartikan alat-alat grafis, photografis, atau elektronis untuk menangkap, memproses, dan menyusun kembali informasi visual dan verbal. Hal tersebut disebabkan kegiatan pembelajaran belum memiliki pandangan penting terhadap penggunaan TIK dalam mengembangkan kualitas pembelajaran. Para pendidik lebih menganggap bahwa materi yang diberikan pendidik secara langsung lebih baik daripada pembelajaran melalui TIK. Padahal sebenarnya hal tersebut menyebabkan peserta didik tidak mau mendapatkan informasi terbaru yang telah ada di internet meskipun sarana dan infrastruktur telah membantu dalam penerapan teknologi informasi. Pola keseharian dari peserta didik tersebut perlu untuk dirubah agar mereka mau memanfaatkan teknologi informasi dan komunikasi. Perubahan tersebut bisa terjadi apabila peserta didik memiliki kesadaran dari diri mereka untuk menggunakan dan menerapkan adanya teknologi informasi didalam kegiatan pembelajaran sehari-hari.

Menurut Oemar Hamalik (1989) menyatakan bahwa media pembelajaran adalah Alat, metode, dan teknik yang digunakan dalam rangka lebih mengefektifkan komunikasi dan interaksi antara guru dan siswa dalam proses pendidikan dan pengajaran di sekolah. Kurangnya kepercayaan pendidik dalam menggunakan TIK juga menjadi kendala dalam pemanfaatan TIK. Dalam hal ini pendidik takut mengalami kegagalan dalam mengajar melalui penggunaan teknologi informasi. Walaupun teknologi modern dalam kegiatan pembelajaran sangat disarankan oleh para pakar pendidikan. Karena dengan penggunaan teknologi informasi tersebut membuat para guru atau pendidik tidak ketinggalan jaman dengan perkembangan dunia pendidikan. Selain itu pendidik juga masih kurang dalam mengintegrasikan penggunaan teknologi informasi dalam penerapan, yaitu tidak mempunyai pemahaman dan keahlian dalam memanfaatkan alat-alat teknologi informasi dan mereka tidak antusias tentang perubahan dan integrasi dengan pembelajaran yang menggunakan alat-alat teknologi informasi dalam kelas mereka. Selanjutnya pendidik juga memiliki sikap yang tidak mau berubah terhadap perubahan yang telah ada. Hal tersebut terjadi dikarenakan pendidik beranggapan bahwa pemakaian TIK dalam proses pembelajaran tidak memperoleh faedah atau keuntungan yang nyata sehingga mereka tidak mau berubah dalam melaksanakan strategi pembelajarannya. 


\section{Solusi Permasalahan dalam Pemanfaatan TIK}

Untuk mengatasi permasalahan dalam pemanfaatan TIK tersebut diperlukan langkah-langkah penyelesaian agar dapat terealisasikan dengan baik pemanfaatan TIK dalam proses pembelajaran. Selanjutnya dijelaskan solusi yang mesti dilakukan dalam mengimpelementasikan pembelajaran yang berdasarkan teknologi informasi sebagai berikut:

Antara pendidik dengan peserta didik harus mempunyai akses teknologi digital dan internet dalam melakukan kegiatan pembelajaran. Dalam hal ini lembaga-lembaga pendidikan harus menyediakan sarana dan prasarana yang layak untuk dipergunakan. Seperti tersedianya laptop atau komputer, LCD, dan jaringan internet. Hal itu tentu akan memudahkan dan membantu kegiatan pembelajaran yang sedang berlangsung.

Pendidik juga harus menyediakan materi pembelajaran yang berkualitas dan bermanfaat baik bagi pendidik sendiri maupun bagi peserta didik. Contoh materi tersebut adalah video pembelajaran. Dengan adanya materi pembelajaran yang baik, diharapkan peserta didik mampu untuk menyerap dengan cepat materi pembelajaran yang telah disampaikan sehingga mereka paham mengenai materi tersebut. Selain itu pendidik juga harus mempunyai pengetahuan dan kompetensi atau keahlian dalam memakai alat-alat teknologi dalam kegiatan belajar agar mereka bisa memberikan materi dengan baik. Apabila pendidik belum bisa menggunakan adanya teknologi tersebut, diberikan bimbingan khusus agar mereka bisa menggunakannya. Dan untuk pendidik yang masih tidak mau menggunakan teknologi tersebut, mereka tetap harus menggunakan adanya teknologi tersebut meskipun tidak langsung mempraktekkan menggunakan teknologi. Contohnya pendidik menyeimbangkan antara metode penyampaian materi menggunakan ceramah dan menggunakan teknologi informasi. Lama kelamaan pendidik tersebut juga akan terbiasa dengan penggunaan teknologi tersebut. Menurut Muslih (2016) menyatakan bahwa siswa yang belajar dengan cara mendengarkan maka ia akan lupa (what I hear, I forget), siswa yang belajar dengan cara melihat maka ia akan menjadi ingat (what I see, I remember), dan siswa yang belajar dengan cara melakukan maka ia menjadi paham (what I do I understand).

Untuk pihak pemerintah daerah harus melakukan observasi di daerahnya untuk mengetahui sarana dan prasarana di lembaga pendidkikan yang ada disana. Tentunya harus siap dalam anggaran atau dana yang cukup untuk melaksanakan dan mengembangkan adanya sarana dan prasarana teknologi informasi dan komunikasi tersebut. Hal ini dilakukan agar pemanfaatan teknologi informasi dapat dilaksanakan secara luas di lembaga persekolahan baik yang berada di pusat kota sampai lokasi terpencil.

Agar pemanfaatan dari teknologi informasi komunikasi dapat berjalan dengan baik tentu saja membutuhkan dukungan dari berbagai pihak seperti, pendidik dan peserta didik dalam mengimplementasikan kegiatan pembelajaran yang menggunakan teknologi informasi. Dukungan dari berbagai pihak tersebut sangatlah penting, karena apabila ada yang tidak mendukung pemanfataan teknologi informasi dan komunikasi tidak dapat bekerja dengan lancar dan baik.

\section{SIMPULAN}

Dengan pemanfatan TIK, peserta menjadi lebih aktif karena dirangsang untuk melakukan eksplorasi ilmu pengetahuan yang didapatnya. Dengan pemanfaatan TIK 
yang baik, maka peserta didik dan pendidik akan mendapatkan pengaruh yang positif dan manfaat dari dari Teknologi yang digunakan. Dengan penggunaan teknologi informasi,membuat para guru atau pendidik tidak ketinggalan jaman dengan perkembangan dunia pendidikan. Dalam pemanfaatan teknologi e-learning, Guru dituntut untuk memiliki pengetahuan dan keterampilannya dalam mengoperasikan media teknologi dalam kegiatan proses belajar mengajar agar mereka bisa memberikan materi dengan baik. Apabila pendidik belum bisa menggunakan adanya teknologi tersebut, diberikan bimbingan khusus agar mereka bisa menggunakannya, selanjutnya apabila pendidik tidak mau menggunakan teknologi tersebut, mereka harus menggunakan adanya teknologi tersebut meskipun tidak langsung mempraktekkan menggunakan teknologi. Pendidik bisa menyeimbangkan antara metode penyampaian materi menggunakan ceramah dan menggunakan teknologi informasi. Lama kelamaan pendidik tersebut juga akan terbiasa dengan penggunaan teknologi tersebut.

\section{DAFTAR REFERENSI}

Aka, K. A. (2017) 'Pemanfaatan Teknologi Informasi Dan Komunikasi (Tik) Sebagai Wujud Inovasi Sumber Belajar Di Sekolah Dasar', ELSE (Elementary School Education Journal): Jurnal Pendidikan dan Pembelajaran Sekolah Dasar, 1, pp. 28-37. Available at: http://journal.umsurabaya.ac.id/index.php/pgsd/article/view/1041.

Anshor, S. (2018) "“Civic-Culture: Jurnal Ilmu Pendidikan PKn dan Sosial Budaya" Pemanfaatan Teknologi Informasi Dan Komunikasi Sebagai Media Pembelajaran', Jurnal Ilmu Pendidikan PKn dan Sosial Budaya, 9924, pp. 88100.

Arsyad, A. (1997). Media Pengajaran . Jakarta: RajaGrafindo Persada.

Chandrawati, S. R. (2010), 'Pemamfaatan E-Learning Dalam Pembelajaran' Jurnal Cakrawala Kependidikan. pp. 172-181. Available at : https://media.neliti.com/media/publications/218616-pemamfaatan-e-learningdalam-pembelajara.pdf

Budiana, dkk. (2015). 'Pemanfaatan Teknologi Informasi Dan Komunikasi Dalam Pembelajaran Bagi Para Guru Smpn 2 Kawali Desa Citeureup Kabupaten Ciamis', Jurnal Aplikasi Ipteks untuk Masyarakat, p. 59-62.

Dewi, S. Z, dkk. (2018). 'Penggunaan TIK sebagai Sumber dan Media Pembelajaran Inovatif di Sekolah Dasar', Indonesian Journal of Primary Education, p 48-53.

Hasrah, H. (2019) 'Pemanfaatan Teknologi Komunikasi Dan Informasi Dalam Pembelajaran PKN', Phinisi Integration Review, 2(2), p. 238 . doi: 10.26858/pir.v2i2.10002.

Hamalik, O. (1989). Media Pendidikan. Bandung: Citra Aditya.

Huda, I.A. (2020). 'Perkembangan Teknologi Informasi Dan Komunikasi (Tik) Terhadap Kualitas Pembelajaran Di Sekolah Dasar', JURNAL PENDIDIKAN Dan KONSELING, p. 143-149.

Tekege, M. (2017). 'Pemanfaatan Teknologi Informasi Dan Komunikasi Dalam Pembelajaran Sma Yppgi Nabire', JURNAL FATEKSA: Jurnal Teknologi Dan Rekayasa, p. 40-52.

Kusmana, A. (2011). 'E-Learning Dalam Pembelajaran', Jurnal Lentera Pendidikan, p. $35-51$. 
Muslih. (2016). 'Pemanfaatan Media Pembelajaran Berbasis ICT pada Lembaga Pendidikan Non-Formal TPQ'. DIMAS , p. 229-230.

Patmanthara, S. (2012). 'Analisis Pelaksanaan Uji Online Pada Kompetensi Teknologi Informasi Komunikasi (TIK) Dan Kesiapan Infrastruktur Di SMA Kota Malang', Jurnal Pendidikan Dan Pembelajaran, p. 28-37.

Putry, H. M. E, dkk. (2020). 'Video Based Learning Sebagai Tren Media Pembelajaran Di Era 4.0', Jurnal Pendidikan Ilmiah, p 1-24.

Restiyani, R. dkk (2014). 'Profil Pemanfaatan Teknologi Informasi Dan Komunikasi (Tik) Sebagai Media Dan Sumber Pembelajaran Oleh Guru Biologi', Jurnal EDUSAINS, p. 50-66. 